\title{
HERMENEUTICS OF DANTE'S INTERPRETATION OF HAPPINESS AS A CONCEPT OF GOOD
}

In Happiness And Contemporary Society : Conference Proceedings Volume (Lviv, March, 20-21, 2021). Lviv: SPOLOM, 2021. P. 266-269. https://doi.org/10.31108/7.2021.59

ISBN 978-966-919-697-2 


\author{
TYTAR Olena \\ Doctor of Sciences in Philosophy, Full Professor, \\ Department of Culture Theory and Philosophy of Science \\ V.N. Karazin Kharkiv National University (Kharkiv, Ukraine)
}

\title{
HERMENEUTICS OF DANTE'S INTERPRETATION OF HAPPINESS AS A CONCEPT OF GOOD
}

The basis of human nature according to Dante is natural inclination, love to good (Aristotelianism, Thomism). God is the highest blessing but some souls are deceived and choose to love the created world, such love can be broken and become a false love, a sin when either the measure or the choice of worthful goal the object of this love is violated. Thus it becomes a transgression punished in Purgatory or a sin punished in Hell. The crucial thing in person's life is a vision of God. In this respect Dante is a Thomist. It is also important to see Comedy as a kind of model of the universe, Dante embodies mathematical, philosophical, Christological, astrological, numerological and other views in it of culture

Keywords: Dante, Thomism, hermeneutics, philosophy of happiness, philosophy

The basis of human nature according to Dante is natural inclination, love to good (Aristotelianism, Thomism). God is the highest blessing but some souls are deceived and choose to love the created world, such love can be broken and become a false love, a sin when either the measure or the choice of worthful goal the object of this love is violated. Thus it becomes a transgression punished in Purgatory or a sin punished in Hell.

Such principles of division of Purgatory and Hell are described in sufficient detail by Auerbach [Auerbach, 2004: p. 116-117]: "When now on the contrary to turn to malefaction, that is to committed sins and not forgiven by God's grace which are punished for in Hell, as a new and decisive moment in sentencing is primarily the consent of the will which is the only to lead to action. Therefore, here in decomposition one should come from decisions of the will. When its consent to an evil cause is given after a calm and mature consideration, in moral sense it is an act committed through real malice: malizia; when a person is forced to make a decision by excessive desire, attraction, the cause of theft is passion, incontinenza. Accordingly, Hell is divided into circles of lesser transgressions committed through passions and circles of heavier sins caused by malice. Thus, here the ascension means transition from petty crime to most serious crimes. With this fundamental difference in moral order of these two kingdoms - namely, thefts are punished in the first one and bad inclinations are cleared away in the other one - it becomes clear why in Hell superbia and invidia which do not correspond in quality to certain kinds of deeds, are absent as special kind of sins; and why ira which being a manifestation of bad love in Purgatory belongs to the second level of the most severe categories of mistakes, and in Hell incontinenza, anger are considered sins, and minor kinds of sin, although in the form of deliberate and vindictive malice it is also present in misdeed caused by malizia and punished in lower circles. There is no place for accidia, the laziness of the heart, in Hell because it leads to inaction; but at the 
entrance of Hell there are cowards who correspond to accidiosi, [the gloomy ones], the fourth circle of Purgatory."

In the 11th song of Hell two hours are left before sunrise (we can find it out by astrological characteristics given by Dante) then the satellites need to hurry: "Heavenly Pisces are floating to the horizon, / The radiant Dipper is approaching Kavr" ("ché i Pesci guizzan su per l'orizzonta, / e 'l Carro tutto sovra' l Coro giace », (XI, 113-114)). Dipper is the constellation Ursa Major, which approaches Kavr (Saurus - northwest wind) before morning when Pisces descend.

D. Merezhkovsky's work describes Boccaccio Dante as an astronomer and astrologer: "Dante was an astronomer and astrologer," - says Boccaccio in interpretations of "The Comedy" "[Merezhkovsky, 2013: p.122].

Further Merezhkovsky writes that Dante is not an abstract thinker and idealist but an artist, a practical man, anthropologist, so he did not understand usury and other deviations from the purpose of a man, an artist, a philosopher:

«Dante is mostly a detached thinker and dreamer of what we call "idealists": he "sees everything," tutto vedea, in Sacquetti's profound words; he knows against whom he is fighting; feels true measure of what he wants to do: oppressive weight of the weight he is lifting. His goal is infinitely difficult: the struggle for the future of Christianity because existing things are baing in decay in the world, and especially at those days: between the death of St. Francis of Assisi and the birth of Dante there begins what we call the "Renaissance" and perhaps it would be more accurate to call it a "degeneration" of Christian humanity; then the "great renunciation" takes place, il gran rifiuto, the apostasy from Christ, the only Unifier of two worlds: Because He is our world, who creates one of the two, poiêsas ta amphotera hen. (Eph. 2:14). Worst of all, in his main will it is to unite the Two into One, the Third, Dante must fight not only the whole world but also himself because sometimes he finds in himself not the union but the "division" of the two worlds: «There was indivision in my soul», la divisione ch'è ne la mia anima; because he was already born, lived and died under the sign of the two "Gemini": Faith and Knowledge" [Merezhkovsky, 2013: p.124].

The crucial thing in person's life is a vision of God. In this respect Dante is a Thomist.

"Man's goal is to see God. In this context the thought of Thomas Aquinas about man and the goal to which his existence is destined, the vision of God, is being developed organically. (...). Based on the natural selflessness of visio Dei (vision of God) and therefore its supernatural, Aquinas sets himself the goal of revealing the presence of paradoxical element in man: the existence of natural desire to contemplate God which however can only be achieved by grace" [Skolla A., Marengo D., Javier PL, 2005: p.211].

U. Eco interprets visio as following: "Returning to the concept of visio, we note once again that this "contemplation" is a useless, disinterested cognition which has nothing to do with hot pleasure characteristics of mystical love just as well as with ordinary sensually perceived and even with empathic assimilation of the object, which in our opinion distinguishes psychology of St. Victor's school. As already mentioned, language refers to knowledge of intellectual order which gives birth to pleasure based on disinterested attitude to the perceived thing: Ad rationem pulchri pertinet quod in ejus aspectu seu cognitione quietetur appetitus (for, the beautiful is characterized by the fact that only with observation and cognition it calms down the wish) (S. Th. I-IIae, 27, 1 ad 
3). Aesthetic pleasure does not seek to own a thing but it is satisfied with its observation, finding proportionality, integrity and clarity in it" [Eco, 2003: p.117-118].

This duality is a combination of art and science, art and nature, the duality of Pisces and Gemini.

Not just an artist, not just a philosopher, but a poet is the creator of new reality, emphasizes Merezhkovsky: "The word "poetry" derived from the Greek word poiein - "to do". Dante, a poet, more than any other great poet is a "doer": all his poetry, the greatest of human affairs, "theurgy", "magic" resurrects the dead by the power of love: Love, which is moving the Sun and other stars. Here, already in mechanics is the beginning of "magic"; "The beginning of all miracles" - necessity. (...) Dante summons the dead in order to know what he, a man, and all the mankind should do. All the living and the dead are united by a supposedly common deal: the struggle against the last enemy, the death: "the last enemy will be destroyed: the death" (I Cor., 15, 26). This first and the last Dante's idea of resurrection of the dead as a possible action of the whole human race, a thought that seems so absurd, impossible, unscientific, not modernday, is expressed by one of the most scientific, modern philosophers, Bergson: "All the beings stick together and are captured in one and the same incredible train. The fulcrum is found in the plant by animal, in the animal by man; and all humanity in space and time is supposedly a great army, moving next to each other and in front and behind of each other, in a powerful movement capable of overcoming many obstacles, maybe even death. "Maybe," says Bergson, and Dante says, "finally," that's the difference. This going to the depths of the future, to the end of history, Dante-Bergson's will to "resurrected magic" comes from the depths of the past, the beginning of history. The moment man appeared on earth, he is already a "magician", "resurrector of the dead" "[Merezhkovsky, 2013: p.119].

It is also important to see Comedy as a kind of model of the universe, Dante embodies mathematical, philosophical, Christological, astrological, numerological and other views in it.

He places himself not only in the center of his life, but also in the time-spacial center of the universe. "According to Benini, three pairs of numbers have for Dante primarily symbolic value: they are 3 and 9, 7 and 22, 515 and 666" [Guenon, 2003: p.457]. But also number 11 (11 songs) is of exceptional importance.

Dante places himself in the center of times - year 1300: 65 centuries passed before Dante and 65 centuries are remained after him, whereas 11 is translated into Latin as LXV which Benini and Guenon interpret as Lux (light, in some respects as Freemasonry or Templarism, their influence), and number 11 is the sum of 6 and 5, and 65 is the ancient Hebrew number of the divine name Adonai.

"Number 22 is related to 7 through the ratio of 22: 7, roughly the ratio of the circle to its diameter, so altogether these numbers represent the circle which for Dante, as well as for the Pythagoreans, is the perfect figure of all (and all the divisions of each of the three worlds have shape of a circle); moreover, number 22 is related to two "elementary movements" in Aristotelian physics: the local motion represented by number 2 and the change represented by number 20, as Dante himself explains in Convito. This is interpretation of these two numbers given by Benini; while acknowledging that it is correct, we must at the same time say that this number does not seem to us as fundamental as he thinks, it even seems to derive from another one which is mentioned as secondary by the same author, while in fact it is more essential: it is number 11, of which 22 is only a derivate. (...) In Hell most completed scenes or episodes into which different songs are divided, include 11 or 22 stanzas (some only 10); there are also 
several introductions and endings in 7 stanzas, and when these proportions are not strictly held to, it is only because the originalal plan of Hell was changed. Taking this into account, why is it impossible to consider number 11 as important as 22? These two numbers are still combined in dimensions that mark boundaries of the "bolgie", a circle of 11 and 22 miles, respectively, but hasn't 22 only derived from 11, the number immanently inherent to the poem? Also number 33 is available which is the number of songs into which each of the three parts is divided; only Hell has 34 but the first part is an all-round introduction supplementing total number to one hundred, in the whole writing.

On the other hand, remembering what rhythm was for Dante, we can assume that he chose a verse of 11 syllables not by chance, also a stanza of three verses that reminds us of the trinity is not random; each stanza has 33 syllables, and the set of 11 and 22 stanzas in question contains 33 and 66 verses; derivatives of 11 which we find here all have special symbolic meaning. So it is not enough to limit oneself as Benini does to placing 10 and 11 between 7 and 22 to form a "tetrachord that bears distant resemblance to Greek tetrachord" and to explain things which are difficult for us to explain here. Indeed, number 11 played a significant role in symbolism of some secret organizations; as for its other derivatives we will recall: 22 is the number of letters of the Hebrew alphabet, its meaning in Kabbalah is known; 33 is number of years of Christ's earthly life which occurs in the symbolic age of Masonic Rosicrucian as well as among the number of grades in Scottish Freemasonry; Arabs have 66 as a numerical meaning of the name Allah, and 99 is the number of main divine attributes according to Islamic tradition; other comparisons can be found as well" [Guenon, 2003: p.458].

Dante's works have been widely known in Ukraine since the beginning of the 19th century. His first book was found in the library of Feofan Prokopovych. The poet was highly valued by Taras Shevchenko. Lesya Ukrainka also turns to works of the famous Florentine. In 1898 she translated the fifth song of "Hell" from "Divine Comedy". It was since then when Dante's tercets sounded in Ukrainian.

Dante's ideas continue to influence the modern Ukrainian society. REFERENCES

1. Ауэрбах Э. Данте - поэт земного мира / Э. Ауэрбах ; пер. с нем. - М. : РОССПЭН, 2004. - 208 с. - Серия «Книга света».

2. Генон Р. Эзотеризм Данте / Р. Генон // Рене Генон. Царство количества и знамення времени. Очерки об индуизме. Эзотеризм Данте. - М. : Беловодье, 2003. - C. 440-477.

3. Ле Гофф Ж. Другое Средневековье: Время, труд и культура Запада / Ж. Ле Гофф ; пер. с фр. - Екатеринбург: Изд-во Урал. ун-та, 2000. - 328 с.

4. Ле Гофф Ж. Становление Европы / Ж. Ле Гофф ; пер. с фр. - СПб. : Александрия, 2007. - 400 с. - Серия «Становление Европы».

5. Мережковский Д. Данте / Д. Мережковский. - М. : Эксмо, 2013. - 605 с.

6. Сколла Анджело, Маренго Джильфредо, Хавьер Прадес Лопес. Богословская антропология / Сколла Анджело, Маренго Джильфредо, Хавьер Прадес Лопес ; пер. с ит. - М. , 2005. - 384 с.

7. Эко Умберто Искусство и красота в средневековой эстетике / Умберто Эко ; пер. с ит. - СПб. : Алетейя, 2003. - 256 с. - Серия «Библиотека средних веков».

8. La Divina Commedia di Dante Alighieri / a cura di Tommaso Di Salvo. - Bologna : Zanichelli, 1987. - XXVIII p., 2000 p. 